Metaphor and Entertainment 
This page intentionally left blank 


\section{Metaphor and Entertainment}

A Corpus-Based Approach to Language in Chinese Online News

Chong Han 


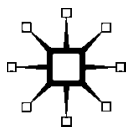

(c) Chong Han 2014

Softcover reprint of the hardcover 1st edition 2014 978-1-137-29803-4

All rights reserved. No reproduction, copy or transmission of this publication may be made without written permission.

No portion of this publication may be reproduced, copied or transmitted save with written permission or in accordance with the provisions of the Copyright, Designs and Patents Act 1988, or under the terms of any licence permitting limited copying issued by the Copyright Licensing Agency, Saffron House, 6-10 Kirby Street, London EC1N 8TS.

Any person who does any unauthorized act in relation to this publication may be liable to criminal prosecution and civil claims for damages.

The author has asserted her right to be identified as the author of this work in accordance with the Copyright, Designs and Patents Act 1988.

First published 2014 by

PALGRAVE MACMILLAN

Palgrave Macmillan in the UK is an imprint of Macmillan Publishers Limited, registered in England, company number 785998, of Houndmills, Basingstoke, Hampshire RG21 6XS.

Palgrave Macmillan in the US is a division of St Martin's Press LLC, 175 Fifth Avenue, New York, NY 10010.

Palgrave Macmillan is the global academic imprint of the above companies and has companies and representatives throughout the world.

Palgrave ${ }^{\circledR}$ and Macmillan ${ }^{\circledR}$ are registered trademarks in the United States, the United Kingdom, Europe and other countries.

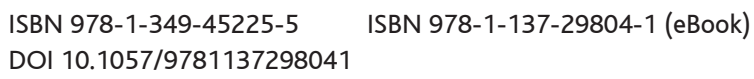

This book is printed on paper suitable for recycling and made from fully managed and sustained forest sources. Logging, pulping and manufacturing processes are expected to conform to the environmental regulations of the country of origin.

A catalogue record for this book is available from the British Library.

A catalog record for this book is available from the Library of Congress. 
To Jintan Han and Jun Shen 
This page intentionally left blank 


\section{Contents}

List of Figures and Tables viii

Acknowledgements $\quad$ ix

Conventions $\quad \mathrm{x}$

1 Introduction 1

2 Entertainment News Genre in China 16

3 Researching Metaphor in Chinese 30

4 Metaphor Analysis and News Corpora 37

5 Metaphor and Onlookers' Entertainment 46

6 Metaphor and Creative and Playful Entertainment 94

7 Metaphor in Chinese 'Entertainmentalised' News 127

8 Metaphor, Entertainment and Contemporary China 145

$\begin{array}{lr}\text { Appendix } & 150\end{array}$

$\begin{array}{lr}\text { Notes } & 152\end{array}$

$\begin{array}{lr}\text { Bibliography } & 164\end{array}$

$\begin{array}{lr}\text { Index } & 179\end{array}$ 


\section{Figures and Tables}

\section{Figures}

1.1 The changing media ecology of news communication 5

3.1 Visual clues in Chinese characters and compound words 32

5.1 Entertainment world is a war zone 61

6.1 Dispersion plot of an extended war metaphor in the news text $6.3 \quad 101$

6.2 The character creation template in role-playing games 116

6.3 Conceptual blending network for 'a gladiatorial combat role-playing game' 117

6.4 A metaphorical construction of the competition candidates in terms of a martial arts clan

7.1 A comparison of three news genres (adapted from Luo 2005: 12)

\section{Tables}

4.1 Corpora in this study

5.1 Overview of source domains and resonance in entertainment news corpus

6.1 Two metaphor candidates in the corpus of Chinese entertainment news

6.2 Eight food terms in the corpus of Chinese entertainment news

7.1 Summary of resonance by source domains in three news corpora 


\section{Acknowledgements}

I would like to express my biggest debt to my supervisors Professor Jane Simpson (The University of Sydney/Australian National University) and Dr Derek Herforth (The University of Sydney), for their dedicated support, unwavering encouragement and invaluable assistance and feedback during my doctoral thesis, upon which this book is based. I am very grateful to Dr Bronwen Dyson (The University of Sydney) for her invaluable advice on my writing.

My special thanks go to my cousin, Zhuo Yin, for providing all the essential technical support for my research and to Associate Professor Shaogen Deng (Jinan University) for assisting me in accessing valuable old Chinese newspapers and collecting relevant literature.

I would also like to thank Associate Professor Bruno Di Biase and Dr Satomi Kawaguchi, my colleagues at the University of Western Sydney, for encouraging me to publish this manuscript.

My deepest gratitude goes to my dear parents, Jintan Han and Jun Shen, for their tremendous love, unconditional support and continuous encouragement. Without them, this book would not have been possible.

Furthermore, I want to thank the three anonymous reviewers for their encouragement, invaluable comments and suggestions. I am also grateful to my editor Olivia Middleton at Palgrave Macmillan for her patience and assistance in the writing and publication process.

The following book chapter, which was originally published by World Scientific, has been adapted into this book:

Han, C. (2012). The Metaphorical World of Chinese Online Entertainment News. In H. Tao \& J. Liu (Eds.), Chinese under Globalization: Emerging Trends in Language Use in China (pp 29-57). Singapore: World Scientific.

Thanks to Elsevier for kind permission to adapt the following paper into this book:

Han, C. (2011). Language Play and Metaphor in Chinese Entertainment News. Journal of Pragmatics, 43(14), 3473-3488. 


\section{Conventions}

1. This book uses the term 'Mandarin Chinese' or 'Chinese' to refer to the standard simplified Chinese writing system used in Mainland China, or the People's Republic of China (PRC). Hànyŭ Pìnyīn is adopted here as the standard Romanisation system for this official standard simplified Chinese writing system. It is noteworthy that all data collected for this study are taken from www. people.com.cn, a news portal in Mainland China, and thus the primary writing system it uses is the official standard simplified Chinese characters. This online news portal now also has a traditional Chinese version and many foreign language versions. For this study, only its simplified Chinese version was accessed.

2. All the Chinese examples in this book (except the long news excerpts) are presented in both Chinese characters and idiomatic English translation. Unless otherwise stated, all translations are mine.

In the examples, the metaphorical expressions are highlighted in bold. In order to preserve the original morphological structure and meaning of the Chinese metaphorical expressions as much as possible, literal translations are given in brackets whenever necessary. The literal translations are then followed by idiomatic English translations. The corresponding Chinese expressions are given in the endnotes.

Example:

"The wedding ceremony of Norika Fujiwara caused ('a hot tide' audience ratings'=) audience ratings to skyrocket."

3. In the running text, individual words or phrases that are intended as metaphorical are presented in italic pinyin, followed by a bracket in which the corresponding Chinese characters, morpheme-by-morpheme glosses and free English translations are given. 
Example:

lāfēng (拉风, pull-wind > overwhelmingly attention-grabbing)

4. Both conceptual metaphors that represent the abstract thoughts underlying metaphors and conceptual domains are shown in upper case.

Example: ENTHUSIASM IS FIRE; BUSINESS IS WAR 